New Industry for the Highlands

Author(s): S. R. Erskine

Source: All Ireland Review, Vol. 2, No. 51 (Feb. 22, 1902), pp. 458-459

Published by: All Ireland Review

Stable URL: http://www.jstor.org/stable/20545861

Accessed: 26-06-2016 05:20 UTC

Your use of the JSTOR archive indicates your acceptance of the Terms \& Conditions of Use, available at

http://about.jstor.org/terms

JSTOR is a not-for-profit service that helps scholars, researchers, and students discover, use, and build upon a wide range of content in a trusted

digital archive. We use information technology and tools to increase productivity and facilitate new forms of scholarship. For more information about JSTOR, please contact support@jstor.org.

All Ireland Review is collaborating with JSTOR to digitize, preserve and extend access to All Ireland Review 
Nordo I think that his breed ?ended with him. There are Irish gentlemen still left of whom we shall.hear, and the world shall hear, when these confusions shall have passed.

Farewell, dear Lord Dufferin. Requiescat in pace profunda.

\section{- - -}

\section{TO HELEN}

Helen, thy beauty is to me,

Like those Nicéan barks of yore

That gently, o'er a perfumed sea,

The weary-worn wanderer bore,

To his own native shore.

On desperate seas long wont to roam,

Thy hyacinth hair, thy classic face,

Thy Naiad airs have brought me hom To the glory that was Greece

And the grandeur that was Rome.

Lo: in yon brilliant window-niche How statue-like I see thee stand,

The agate lamp within thy hand

Ah, Psyche from the regions which Are holy-land :-

Edgar Allan Poe.

Is not this a gem? Pure, chaste lovely beyond the powers of languitge to praise in fit words. And it is unique, even in Poe, for it has not that luscious melody and voluptuous refraining of which he was so fond, and for which he ought to be such an example and admonition to the poetically inclined, to those who won't write sensible verse and can't write verses that will sing.

\section{THE POOR CRIPPLE:}

Our ancestors did not care for threevolume or for one-volume novels. Even Kipling's stories would have seemed to them dreadfully and needlessly long and tedious. They liked their fiction brief, concise, elliptio, and leaving much to the imagination. Here is an example

There was ouce a poor cripple who was accustomed to be carried upon a hand. barrow from one house to that which lay next. On a certain day two fine young men were engaged in this charitable labour and carrying this helpless creature between them upon a barrow. 'They were noted hurley-players. Patrick and Michael were their names Patrick and Michael were their names.
Patrick was long-shanked, Michael shorter as to his legs, but very active.

They crossed a great field in which there were cattle. Amonerst the cattle was a bull who, roaring dreadfully, was a bull who, roaring dreadfully, bearers dropped the barrow and the helpless creature, and made for the nearest fence as liast as they could run

Now, who do you think was the fir t to reach that fence! Well, it was neither Patrick nor Michael!

It was the poor cripple:

\section{DR. GAFFNEY ON RENT.}

Dr. Gaffney, Bishop of Meath, in his recent Iencen Pastoral, declared that "rent must, and will cease." Rent will never cease. As long as one kind of land is worth $£ 5$ an acre, and another kind of land worth 2s. 6d. an acre there will be rent.

\section{O'CURNAN'S LAMENT.}

The followingilament is one of the pearls of Irish peasant poetry. It has been finely translated by Dr. Sigerson in his "Bards of the Gael and Gall," but his rendering, usually so close to the original, is in this case a free one, and is not of much use for learners. We therefore append a literal prose version. The story connected with the poem is that U'Curnan loved the daughter of a farmer in the County Waterford, in whose service he lived, and was promised her hand if he served for her seven years. At the end of the time when his reward was drawing nigh, his master sent him with a load of butter to the Cork market, and on his return $O$ 'Curnan found that his love had been hastily wedded to another and wealthier suitor. He lost his senses under the blow, and became a wandering beggar for the rest of his life. The poem is said to have been composed by him; and, certainly, it has a simplicity and intensity which seem to tell of a personal orrow, and which form a striking contrast to the love verses, often so cold and tedious, elaborated by the profesional 18th century poets, such as 'Rahilly and O'Sullivan.

a mäıre milır opeás o'fás an cnead ro ap mo lâp

nac léisirfead a nolleän na foota,

ir so mbeapfainn oap mo läim oá ozuisfea féin mó cár

nac leisfeá mo bãr annro san fóptin.

ní castim unra bió, ní coolasm neul ó luisim,

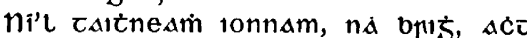
rsăl beas;

muna bpasaló mé uain nó rgit ón

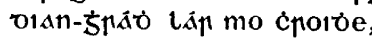

ni maiplíó mé beo lá, mí, na păite.

! nỉl fror ná lelśear mo ç̣áo as aon neać beo le fasánl,

ace amán as an mnaol nó-dear oo breus mé.

níl mo lésear ap muip ná cháis, ni’l ré ap luib nă lāim

ni'l mo lésear act leac-ra féin, blád na h-ôse.

ni altnisım ceapc tan cuac, ni altnisim rear tap fuace căproe,

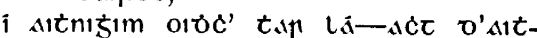

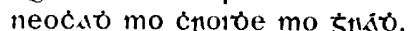

Oi otasato pí 1 otjit asur le fólptin.

! fóı, a cumann, oéın; caban óam pós oo' beut

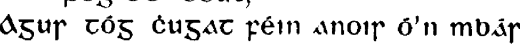
mé,

no onouis òm leaba caol 1 scómia clän bos oéal, scomzap nub an oaoll asur a issue of Mr. Standish O'Grady's AlL cấrioe.

ni beo mo beo ač eus, ni slóp mo ślô Donegal Carpet Industry." $\Delta C \bar{C}$ इAOt,

Now, it seems to me, that if this

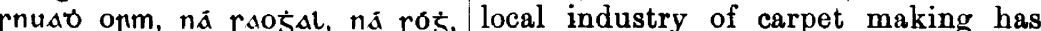
nà rläınce:

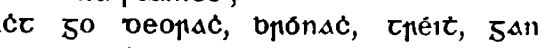
ceol, san rpópe ná péim,

1 noaon-önulo a'r 1 nois 'ra bpein le STíto oute.
[TRANSLATION.]

ary, sweet and fair, that left this wound in my bosom

wound that the Island of Fodla has nothing to heal,

swear by my hand that if thou knewest my case

Thou wouldst not let me die here without succour.

do not eat an ounce of food, nor sleep a wink when I lie down,

are is no jny nor strength in me, hut a little shadow:

nless I get respite or rest from the fierce love in my heart's core

shall not live a day, a month, nor a quarter.

h there is no knowledge nor cure for my woe to be found in any creature ave only in the too-fair woman that deceived me,

cor me on sea or shore, none in any herb nor in any hand;

cure for me but in thee alone, flower of maidens.

not heat from cold,

never know my friends,

know not night from day-but my

heart would know my Love

f she would come to me timely with succour.

Oh succour me, dear one; give me a kiss from thy mouth.

And lift me up to thee from death

Or bid them make for me a narrow bed, a coffin of a board of bog deal,

the dark neighbourhood of the worm nd his friends.

is not life, but death, my voice is no voice, but a wind; prosperity, nor health, power,

In captivity [ $\mathrm{I}$ go] and in affliction, in the pain of my love of thee.

NEW INDUSTRY FOR THE HIGHLANDS.

I have before me that fine Highland newspaper, the Oban Times, which in this issue a reprint from he All Ireland Review of Mr. Louis Beattie's interesting article, and also the following letter from the Hon. Erskine, which exhibits that ruculent young Caledonian in a new and, I think, more welcome light, one in which, to say the least, he looks TO THE EDITOR OBAN TIMES.

" 30 Melville Street, Perth,

"Sir,-Everyone who has the interest of the Highlands and the Islands at heart must desire to do everythir:g in his power to promote the prosperity of the inhabitants. Therefore, all schemes which have that laudable object in view are surely entitled to ery consideration. achieved such good results in Ireland there is no reason why a similar industry should not be started in our own Highlands and Island, wherein, as you well know, conditions very similar to " 2nd February, 1902. 
those which exist in Western Ireland largely obtain. Moreover, the application of the principles underlying Celtic art to the production of carpets, rugs, etc., would result in the establishment of a series of industries which would powerfully appeal to all those whose eye for native colour and form has not been spoiled by the monstrous achievements of Birmingham, Axminster, and other industrial centres, where quantity is the principal consideration controlling their mechanical output. Instead of Persian, it would be easy to apply Celtic art to the manufacture of these carpets, going to the best sources of Celtic inspiration for colour and form, and relying on the genius and iutuitive artistic perception of the Celt in the same degree and manner as Persions are accustomed to rely on their native Persian art in the production of those beautiful wares for which their country is so justly and universally celebrated.

The Celtic Renaissance should surely aim at material, as well as the intellectual improvement; for without the one there can be no great progress in the other. The two movements should go hand in hand, so as to assist and encourage one another to the attainlove their race and country must always have in view - the rehabilitation of the Gaels, and their restoration to their proper place among the people of the world.-I a m, etc.

\section{S. R. Erskine.}

[Bravo! Cock of the North. Now, after penning this wise and besutiful letter, don't you feel a great deal happier and more virtuous than you did after writing me that long laboured epistle, in which you so roundly abused us, poor Irish Protestants, who never did you any harm ?-ED.]

\section{LAND QUESTION.}

\section{THE BRITISH STATESMAN AND} THE IRISH LAND QUESTION.

Dear Mr. TottenhaM - Thank for your interesting and instructive pamphlets about the land question. To others they may seem a little out of and how he might make us happier and date; they are not so to me, to whom more virtuous?

the past and the future are quite as Not he. He thinks about inatters important as the present in their con- more important; and, when he has tributions to the opinions I am forming finished, just turns on his pillow, and and the views which I may publishcorcerning this question of questions : that of the right and natural relations between man and the earth, virtually important for every nation, especially for this nation, surrounded as we are by the shadows of great changes approaching and imminent. Lord Salisbury's inept and clumsy allusions to Ireland as a source of danger to the Empiregreater, I think, he said " infinitely greater" - than that offered by the Boers, was just his way of preparing the mind of the British democracy for a great, drastic, probably final stroke of "Conservative" land legislation for in that line of endeavour you can a hardly expect that the next, and probably last, will be one characterised by much tenderness or consideration for the class and the interests which you represent.

I have observed that the British Statesman. when he desires to legislate against an Irish interest, withdraws his favour and protection from that in-
terest, so as to prepare the minds of its representatives for the treatment which
he is about to administer. So, in 1879 and 1880, Gladstone gave Parnell and the Land League a free hand in Ire he Land Bill of 1881 . I admired your denunciation of our Chief Secretary, which was published last week in the with you that the inaction of our gone out from London that the Execu- disappear and a different tenure take ive are to make things is uncomfort- its place.

ble as possible for Irish landowners and I venture to think that this change rent receivers, and get them in this will take place gradually not suddenly. mon an Irish In your letters to $X$ you appear to , so their minds will be prepared for to such a change is in the reluctance of acceptance of the Government land the present owners of land to acquiesce , which, from all $I$ can learn, is in a new order of things, and that if ely to be of a very drastic nature. they were persuaded to change their There is no "supiness" at all; or, if view and to join in an application to the is it is a supineness calculated the Govment for an immediate settleand premeditated-a card deliberately ment, coming to some understanding played with a clear purpose in view. meantime with the tenants on the British Administrations are never matter of price, all difficulty would supine: the interests of their country then be over, and the business might and Empire, and those of their own be concluded at once. I think that is a Party, do not permit them to indulge in mistake. There are several other uch a luxury. The British Government points, some of them of great importhas, in my opinion, always dealt intelli- ance, to be considered. 'The change of gently, very intelligently, with the a system of land tenure cannot be rish problem from its own British accomplished as one might throw off an point of view. When fierce and coer- old jacket and put on a new one. How cive it is with a clear purpose, and many years did it take to complete when supine it is with a clear purpose. the change of land system in Prussia That absurd speech of Lord Salisbury's initiated by Hardenberg? If I am was delivered with a purpose. It will correctly informed a good many. And be succeeded in due course by another, in that case the Government did not in which he will enlarge on the desire- require to be pressed; the scheme was bleness and necessity of giving the soil their own, and they used all their of Ireland to the people in order to con- power to carry it through; nor was the ciliate their affection and loyalty to the delay from opposition of the landowners, Empire, and abolish the danger which, for they seem to have given very little. as he informed the Junior Constitu- The delay, I take it, arose out of the national Club, was far greater than that ture of the case and the difficulties that which has arisen out of South Africa. must always occur in carrying out a The British Statesman, as you will change of a large and complicated readily understand, is governed in his nature. If you allow me, I will return action by his Party interests and those to this subject in another letter, and of his own people, never by justice or point out in more detail some of the by sentiment.

reasons which induce me to think that this business must of necessity occupy considerable time.

[Not, dear M., I believe, if we are in earnest about it. If in earnest, we can settle thingsat once, provisionally, working back in each case upon the proisional arrangement after an accurate and final arrangement. Then the I perceive from your writings and provisional arrangement, if properly
correspondence that you are a thinker, framed, might be accepted by many as correspondence that you are a thinker, framed,
and invite you to think about the less final.

pparent, yet tremendously important Example-A provisional arrangement aspects of the Land Question. It is in the Land Act of 1881 that Griffith' uid now, and the settlement of it may: Valuation should be the standard of be made to flow into such shapes and rent till the Land Court should in each take such impressions as we prepare for case decide the fair rent. You underit. Every kind of property you can think stand what I mean.-ED. A.I.R.] of is a mode or form assumed by land

What are we ourselves but a mode of DEAR MR. EDITOR,-I promised to and, "dust of the earth." But, indeed, I explain my reasons for thinking that the have so many things to say on the sub- change in the system of land tenure now ect that I hardly know where to begin. in progress will be a gradual, not a sud Just one thing to conclude with for den, change. It will be admitted that the present. Within the last half-hour land purchase depends on the assent of lady told me that the ground rent of the persons who are to supply the money er house and garden in the suburbs of for the operation; that is to say, on the Dublin was $£ 12$ a year. The ground is assent of a majority of the taxpayers of ess than an acre. So, land then, yields the United Kingdom. No so-called some £24 an acre per annum. How is it "offer" is valid till endorsed by this we hear nothing of the invisible demon assent.

landlord of the cities and towns, while May I assume, I think I safely may, that yo scheme of purchase that involved 